\title{
Pengaruh Informasi Akuntansi Terhadap Kinerja Manajerial dengan Tiga Variabel Moderating (Studi Empiris Pada BPR di Kabupaten Bogor)
}

\section{Dona Primasari, Isbandriyati Mutmainah}

\author{
Fakultas Ekonomi Universitas Nusa Bangsa Bogor \\ Jl. KH.Soleh Iskandar KM.4 Cimanggu Bogor \\ Email:dona_primasari@yahoo.com
}

\begin{abstract}
This research is based on the importance of accounting information to the manager's performance evaluation, which is moderated with environment uncertainty, task uncertainty, and business strategy. It was used the population of Bank Perkreditan Rakyat on Kabupaten Banyumas. The influence of accounting information to managerial performance was analyzed by using original least square regression, and the influence of three moderated variable (environment uncertainty, task uncertainty, and business strategy) to manager performance were analyzed by using Moderated Regression Analysis (MRA).

The analysis result showed that accounting information variable influenced manager performance significantly. Meanwhile, the variables of environment uncertainty, task uncertainty, and business strategy did not moderate the influence of accounting information to manager performance.In other words, those three variables could not be said as moderated variables. The result showed indication of the importance of accounting information in doing management's function
\end{abstract}

Keywords: accounting information, the manager's performance evaluation, environment uncertainty, task uncertainty, and business strategy.

\section{PENDAHULUAN}

Perkembangan teknologi informasi mengakibatkan lingkungan bisnis mengalami perubahan dengan pesat, sehingga perusahaan-perusahaan harus melakukan penyesuaian terhadap perubahan tersebut terutama dengan kondisi ketidakpastian yang ada dengan melakukan strategi yang lebih baik. Bank adalah salah satu dari perusahaan yang bergerak dalam bidang jasa, dimana bank juga menghadapi kondisi ketidakpastian (contigency) sehingga diperlukan informasi yang sesuai terutama informasi akuntansi dan informasi non akuntansi serta pengendalian manajemen yang baik agar kinerja manajerial meningkat.

Penggunaan informasi akuntansi sebagai alat ukur untuk mengevaluasi kinerja manajer telah mengundang serangkaian perdebatan yang kemudian mendorong para peneliti untuk melakukan penelitian di bidang ini. Penelitian ini menguji tiga variabel kontijensi sebagai variabel moderating yaitu ketidakpastian lingkungan, ketidakpastian tugas, dan strategi bisnis dengan informasi akuntansi dalam mempengaruhi kinerja manajerial dengan judul Pengaruh Informasi Akuntansi Terhadap Kinerja Manajerial Dengan Tiga Variabel Moderating (Studi Empiris Pada Bank Perkreditan Rakyat di Kabupaten Bogor).

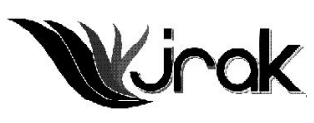

Jurnal Reviu Akuntansi dan Keuangan ISSN: 2088-0685 Vol.1 No. 2, Oktober 2011 Pp 115-126 


\section{Pengaruh Informasi Akuntansi...}

Pendekatan teori kontijensi pada akuntansi manajemen didasarkan pada premis bahwa tidak ada sistem akuntansi manajemen secara universal selalu tepat untuk diterapkan pada seluruh organisasi dalam setiap keadaan, tetapi sistem manajemen itu tergantung juga pada faktor-faktor situasional yang ada dalam organisasi. Dengan didasarkan pada pendekatan kontijensi maka ada kemungkinan terdapat variabel penentu lainnya yang saling berinteraksi, selaras dengan kondisi tertentu yang dihadapi.

Masalah utama yang dihadapi manajer pada pendekatan teori kontijensi adalah menentukan kesesuaian ( $f i t$ ) desain organisasi dengan kondisi lingkungan (Mardiyah dan Gundono, 2002). Dalam teori kontijensi yang telah dikembangkan, menggunakan tingkat ukuran ketidakpastian dan kompleksitas lingkungan yaitu lingkungan eksternal dan lingkungan internal. Para peneliti telah banyak menerapkan pendekatan kontijensi guna menganalisis dan mendesain sistem kontrol, khususnya di bidang akuntansi manajemen seperti penelitian bidang akuntansi untuk melihat hubungan variabel-variabel kontekstual seperti ketidakpastian lingkungan (Gordon dan Narayanan, 1984, Govindarajan, 1986), ketidakpastian tugas (Hirts, 1983).

Beberapa definisi tentang informasi informasi telah diberikan oleh para ahli. Menurut Arnold dan Hope dalam Komara (2003) informasi akuntansi merupakan informasi utama berupa finansial yang digunakan untuk mengambil keputusan, pengendalian, dan implementasi keputusan. Belkoui (1986) mendefinisikan sebagai informasi kuantitatif suatu entitas ekonomis yang berguna untuk membuat ekonomis dalam hal pemilihan alternatif-alternatif keputusan.

Ketidakpastian lingkungan adalah kondisi lingkungan eksternal yang dapat mempengaruhi operasionalisasi perusahaan (Oktavianus, 2002) dan diidentifikasi sebagai variabel kontekstual yang penting dalam desain sistem akuntansi manajemen (Gordon dan Miller dalam Imron, 2003). Ducan (1973) dalam Imron (2003) mendefinisikan ketidakpastian lingkungan ini sebagai: 1) ketiadaan informasi tentang faktor-faktor lingkungan yang berhubungan dengan situasi pengambilan keputusan, 2) tidak diketahui outcome dari keputusan tertentu tentang seberapa besar kerusakan atau kerugian jika keputusan yang diambil salah, 3) ketidakmampuan untuk menilai kemungkinan pada berbagai tingkat keyakinan tentang bagaimana faktor lingkungan dapat mempengaruhi berhasil atau tidaknya keputusan.

Ketidakpastian lingkungan sering menjadi faktor yang menyebabkan organisasi melakukan penyesuaian terhadap kondisi organisasi dengan lingkungan. Top manajemen akan mengalami ketidakpastian lingkungan yang dipersepsi tinggi, jika merasa lingkungan tidak dapat diprediksi dan tidak dapat memahami bagaimana komponen lingkungan akan berubah (Miliken, 1987; Imron, 2003). Sebaliknya ketidakpastian lingkungan rendah (lingkungan relatif stabil, individu (top manajemen) dapat memprediksi keadaan sehingga langkah-langkah yang akan diambil dapat direncanakan dengan lebih akurat.

Hickson dan Fazli (2000) mendefinisikan ketidakpastian tugas sebagai kekurangan informasi tentang kejadian kejadian di masa depan sehingga alternatifalternatif tindakan dan outcome yang akan dihasilkan sulit diprediksi. Penelitian Kim (1998) dan David (2001) membagi ketidakpastian tugas dalam dua dimensi yaitu: 1) dimensi task variability yaitu sejumlah kasus yang luar biasa atau tidak diharapkan atau kejadian yang tidak tertanggulangi, 2) dimensi task analyzability yaitu pengetahuan atau pemahaman yang kongkrit mengenai suatu kegiatan dan tingkat kompleksitas proses pelaksanaan tugas.

Terkait dengan ketidakpastian tugas, Hirts (1981) membagi menjadi tiga yaitu ketidakpastian tugas tinggi, ketidakpastian tugas sedang, dan ketidakpastian tugas rendah. Ketidakpastian tugas tinggi dapat diartikan sebagai kondisi tugas yang tidak dapat dipahami dengan baik oleh karyawan. Dari ketidakpahaman atas tugas tersebut maka karyawan tidak memiliki pengetahuan yang cukup mengenai apa yang harus dilakukan. Sedangkan ketidakpastian tugas rendah 
merupakan suatu kondisi dimana karyawan memahami dengan baik terhadap tugasnya.

Strategi bisnis terdiri dari empat yaitu prospector, defender, analyzer, dan reactor (Milles dan Snow, 1987 dalam Yubiharto, 2003). Tipologi strategi ini telah banyak digunakan dalam penelitian di bidang akuntansi antara lain oleh Govindarajan dan Gupta (1985); Simon (1987); Chong (1997); dalam Yubiharto (2003). Tipologi ini didasarkan pada tingkat perubahan produk maupun pasar yang dialami oleh perusahaan akibat strategi yang diterapkan.

Kinerja (performance) adalah hasil kerja yang dapat dicapai oleh seorang atau sekelompok orang dalam suatu organisasi, sesuai dengan wewenang dan tanggung jawab masing-masing, dalam upaya mencapai tujuan organisasi secara legal, tidak melanggar hukum dan sesuai dengan moral maupun etika. Kinerja manajemen didefinisikan sebagai proses yang dilalui manajer untuk memastikan bahwa aktivitas dari para karyawan dan output yang dihasilkan sesuai dengan tujuan organisasi.

\section{METODE}

\section{Desain Penelitian}

Jenis penelitian yang digunakan dalam penelitian ini adalah penelitian pengujian hipotesis (hypotheses testing) yaitu penelitian yang menjelaskan fenomena dalam bentuk hubungan antar variabel. Tipe hubungan antar variabel dalam penelitian ini adalah hubungan sebab akibat atau sering disebut dengan hubungan kausalitas. Jenis data yang digunakan adalah data subyek yaitu data penelitian yang berupa opini, sikap, pengalaman atau karakteristik dari seseorang atau sekelompok orang yang menjadi subyek penelitian (responden) (Indriantoro dan Supomo,1999). Sumber data yang dipergunakan dalam penelitian adalah data primer dalam bentuk persepsi responden (subyek) penelitian dan instrumen yang digunakan adalah kuesioner atau angket.

Populasi penelitian ini meliputi para manajer yang bekerja pada Bank Perkreditan Rakyat (BPR) di Kabupaten Bogor. Adapun sampel yang digunakan adalah manajer keuangan, manajer personalia, manajer administrasi, teknologi informasi, dan manajer pemasaran. Penggunaan manajer sebagai sampel dalam penelitian ini karena pertama, masing-masing manajer pada BPR memiliki persepsi yang berbeda mengenai ketidakpastian, strategi dan kinerja dan manajer juga bertindak sebagai pimpinan divisi yang diberi wewenang dan tanggung jawab terhadap kebijakan pengaturan bisnis dan informasi perusahaan. Teknik pengambilan sampel dilakukan dengan cara sensus sampling yaitu teknik penentuan sampel dengan mengambil semua sampel yang ada. Hal ini dilakukan karena jumlah BPR di Kabupaten Bogor hanya 28 buah. Proses pengiriman kuesioner dilakukan dengan cara mendatangi langsung ke kantor BPR sesuai dengan alamat yang diberikan Bank Indonesia.

Kuesioner didesain terdiri dari dua bagian. Bagian pertama, terdiri dari instrumen pertanyaan yang menkonstruksi variabel penelitian. Bagian kedua ini berisi pertanyaan dengan jawaban menggunakan skala Likert (1 sampai 5). Data penelitian yang dibutuhkan terdiri dari data primer dalam bentuk persepsi responden, bagian kedua berisi deskripsi responden, merupakan uraian responden secara demografis.

Variabel penelitian menggunakan instrumen yang telah dikembangkan dan digunakan oleh peneliti-peneliti terdahulu. Penggunaan instrumen-instrumen dari penelitian-penelitian terdahulu dimungkinkan karena telah diuji validitas dan reliabilitasnya. Variabel dalam penelitian ini terdiri dari variabel independent atau variabel bebas dan dependent atau variabel terikat. Variabel independent adalah variabel yang mempengaruhi variabel lain dalam hal ini adalah informasi akuntansi, sedangkan ketidakpastian lingkungan, ketidakpastian tugas dan strategi bisnis merupakan variabel moderator yaitu variabel yang dapat memperkuat atau 
Pengaruh

Informasi

Akuntansi...

118

memperlemah hubungan antara variabel independent dan variabel dependent. Adapun variabel dependent atau variabel yang dipengaruhi dalam penelitian ini adalah kinerja manajerial.

\section{Teknik Analisis Data}

\section{Uji Kualitas Data}

Menurut Hair et al (1995) kualitas data yang dihasilkan dari penggunaan instrumen penelitian dapat dievaluasi melalui uji reliabilitas dan validitas. Uji tersebut masing-masing untuk mengetahui konsistensi dan akurasi data yang dikumpulkan dari penggunaan instrumen. Ada 2 prosedur yang dilakukan untuk mengukur reliabilitas dan validitas data, yaitu: uji konsistensi internal terhadap jawaban responden atas instrumen penelitian dan uji validitas konstruk dengan cara mengkorelasikan antara skor masing-masing item dan skor totalnya. Keterangan dari kedua uji kualitas data adalah sebagai berikut:

a. Uji konsistensi internal (reliabilitas) ditentukan dengan koefisien cronbach alpha. Suatu konstruk atau instrumen dikatakan reliabel jika memberikan nilai cronbach alpha di atas 0,60 (Nunnally, 1967 dalam Imam, 2005).

b. Uji homogenitas data (validitas) dengan uji person correlation. Bila korelasi tiap faktor tersebut positif dan besarnya 0,3 ke atas maka instrumen tersebut memiliki validitas konstruksi yang kuat (Sugiyono 2008).

\section{Uji Hipotesis}

Analisis statistik yang digunakan adalah analisis regresi sederhana dan beranda sebagai model yang memprediksi hubungan kausal antara variabel dependen dengan beberapa variabel independen. Regresi linear sederhana untuk menguji hubungan antara informasi akuntansi dengan kinerja manajerial dan menguji hubungan ketiga variabel moderating (ketidakpastian lingkungan, ketidakpastian tugas, dan strategi bisnis) dengan kinerja manajerial. Moderated regression analysis $(M R A)$ digunakan untuk menentukan hubungan interaksi antara tiga variabel oleh satu variabel sebagai variabel moderating (Nunnally, 1994). Persamaan statistika yang digunakan adalah sebagai berikut:

1. $\mathrm{KM}=\mathrm{a}+\mathrm{b}_{1} \mathrm{INF}+\mathrm{e}$

2. $\mathrm{KM}=\mathrm{a}+\mathrm{b}_{1} \mathrm{INF}+\mathrm{b}_{2} \mathrm{KL}+\mathrm{b}_{3} \mathrm{INF} * \mathrm{KL}+\mathrm{e}$

3. $\mathrm{KM}=\mathrm{a}+\mathrm{b}_{1} \mathrm{INF}+\mathrm{b}_{2} \mathrm{KT}+\mathrm{b}_{3} \mathrm{INF} * \mathrm{KT}+\mathrm{e}$

4. $\mathrm{KM}=\mathrm{a}+\mathrm{b}_{1} \mathrm{INF}+\mathrm{b}_{2} \mathrm{ST}+\mathrm{b}_{3} \mathrm{INF} * \mathrm{ST}+\mathrm{e}$

$$
\begin{aligned}
& \text { Dimana: } \\
& \mathrm{KM}=\text { Kinerja Manajerial } \\
& \mathrm{INF}=\text { Informasi Akuntansi } \\
& \mathrm{KL}=\text { Ketidakpastian Lingkungan } \\
& \mathrm{KT}=\text { Ketidakpastian Tugas } \\
& \mathrm{ST}=\text { Strategi Bisnis } \\
& \mathrm{a} \quad=\text { intercept } \\
& \mathrm{e} \quad=\text { error }
\end{aligned}
$$

\section{HASIL DAN PEMBAHASAN}

\section{Gambaran Umum Responden}

Data penelitian dikumpulkan dengan menyampaikan 140 kuesioner kepada para manajer divisi pada masing-masing BPR di Kabupaten Bogor. Dari 140 res$^{-}$ 
ponden sebanyak 70 responden menyerahkan jawabannya sampai akhir bulan Juni 2009. Sehingga total jawaban kuesioner yang dapat dikumpulkan adalah 70. Jumlah pengembalian kuesioner dalam penelitian ini ditunjukkan secara keseluruhan dalam tabel 1

\begin{tabular}{lc}
\hline Total Pengiriman Kuesioner & 140 \\
Kuesioner yang kembali sampai Agustus 2009 & $\mathbf{7 0}$ \\
Kuesioner yang tidak dapat digunakan & - \\
Total Kuesioner yang digunakan & $\mathbf{7 0}$ \\
Tingkat pengembalian (response rate) & $\mathbf{7 0 / 1 4 0 = \mathbf { 5 0 } \%}$ \\
\hline Sumber: Data primer diolah 2009 &
\end{tabular}

Sumber: Data primer diolah 2009

Adapun profil 70 responden yang berpartisipasi dalam penelitian ini ditunjukkan pada table 2 sebagai berikut:

\begin{tabular}{lcc}
\hline \multicolumn{1}{c}{ Keterangan } & Jumlah & Persentase \\
\hline Gender: & 38 & $54,29 \%$ \\
Pria & 32 & $45,71 \%$ \\
Wanita & & \\
Pendidikan: & 65 & $92,86 \%$ \\
S1/Sarjana & 5 & $7,14 \%$ \\
S2 & & $77,14 \%$ \\
Lama bekerja di Bank: & 54 & $22,86 \%$ \\
3-5 tahun & 16 & \\
6-10 tahun & & $24.29 \%$ \\
Jabatan: & 17 & $17,14 \%$ \\
Manajer Keuangan & 12 & $18,57 \%$ \\
Manajer Personalia & 13 & $17,14 \%$ \\
Manajer Administrasi & 12 & $22,86 \%$ \\
Manajer Teknologi Informasi & 16 & \\
Manajer Pemasaran & & \\
\hline
\end{tabular}

Sumber: Data primer diolah 2009

\subsection{Deskripsi Variabel}

\begin{tabular}{lccccc}
\hline \multicolumn{1}{c}{ Variabel } & Teoritis & \multicolumn{3}{c}{ Sesungguhnya } \\
\hline & Kisaran & Mean & Kisaran & Mean & SD \\
\hline Informasi Akuntansi & $5-50$ & 15 & $24-40$ & 32,24 & 3,759 \\
Ketidakpastian Lingkungan & $5-30$ & 15 & $0-30$ & 19,01 & 6,979 \\
Ketidakpastian Tugas & $5-65$ & 15 & $0-42$ & 29,26 & 8,141 \\
Strategi Bisnis & 5 & 3 & $3-6$ & 4,19 & 1,011 \\
Kinerja Manajerial & $5-50$ & 15 & $22-40$ & 32,99 & 3,88 \\
\hline
\end{tabular}

Sumber: data primer diolah 2009

Berdasarkan tabel 3 di atas, variabel informasi akuntansi mempunyai bobot kisaran teoritis sebesar 5 sampai dengan 50 dengan nilai rata-rata sebesar 15 . Sedangkan pada kisaran sesungguhnya, mempunyai bobot kisaran 24 sampai dengan 45 dengan nilai rata-rata sebesar 34,03 dan standar deviasi sebesar 3,960. Nilai rata-rata jawaban variabel informasi akuntansi untuk kisaran sesungguhnya di atas nilai rata-rata kisaran teoritis, maka dapat diartikan bahwa pengaruh variabel informasi akuntansi terhadap responden tinggi.

Variabel ketidakpastian lingkungan mempunyai bobot kisaran teoritis sebesar 5 sampai dengan 30 dengan nilai rata-rata sebesar 15. Sedangkan pada kisaran sesungguhnya, mempunyai bobot kisaran 0 sampai dengan 30 dengan nilai ratarata sebesar 19,01dan standar deviasi sebesar 6,979. Nilai rata-rata jawaban variabel ketidakpastian lingkungan untuk kisaran sesungguhnya di atas nilai rata-rata kisaran teoritis, maka dapat diartikan bahwa pengaruh variabel ketidakpastian lingkungan terhadap responden tinggi.

Variabel ketidakpastian tugas mempunyai bobot kisaran teoritis sebesar 5 sampai dengan 65 dengan nilai rata-rata sebesar 15 . Sedangkan pada kisaran sesungguhnya, bobot kisaran 0 sampai dengan 51 dengan nilai rata-rata sebesar 36,77 dan standar deviasi sebesar 9,949. Nilai rata-rata jawaban variabel ketidak-
JRAK

Tabel 1: Rincian Penerimaan dan Pengembalian Kuesioner

Tabel 2: Profil Responden

Tabel 3: Statistik Deskriptif Variabel Penelitian 


\section{Pengaruh Informasi} Akuntansi...

Tabel 4: Hasil Uji Reliabilitas

Tabel 5: Hasil Uji Validitas pastian tugas untuk kisaran sesungguhnya di atas nilai rata-rata kisaran teoritis, maka dapat diartikan bahwa pengaruh variabel ketidakpastian tugas terhadap responden tinggi.

Variabel strategi bisnis mempunyai bobot kisaran teoritis sebesar 5 dengan nilai rata-rata sebesar 3 . Sedangkan pada kisaran sesungguhnya, mempunyai bobot kisaran 3 sampai dengan 6 dengan nilai rata-rata sebesar 4,19 dan standar deviasi sebesar 1,011. Nilai rata-rata jawaban variabel strategi bisnis untuk kisaran sesungguhnya di atas nilai rata-rata kisaran teoritis, maka dapat diartikan bahwa pengaruh variabel strategi bisnis terhadap responden tinggi.

Variabel kinerja manajerial mempunyai bobot kisaran teoritis sebesar 5 sampai dengan 50 dengan nilai rata-rata sebesar 15. Sedangkan pada kisaran sesungguhnya, mempunyai bobot kisaran 0 sampai dengan 40 dengan nilai ratarata sebesar 31,25 dan standar deviasi sebesar 8,202. Nilai rata-rata jawaban variabel kinerja manajerial untuk kisaran sesungguhnya di atas nilai rata-rata kisaran teoritis, maka dapat diartikan bahwa pengaruh variabel kinerja manajerial terhadap responden tinggi.

\subsection{Uji Kualitas Data}

Hasil pengujian realibilitas dan validitas data menunjukkan tingkat kekonsistenan dan keakurasian yang cukup baik. Pada uji reliabilitas, konsistensi internal koefisien Cronbach's Alpha menunjukkan tidak ada koefisien yang kurang dari nilai batas minimal 0,60 . Sedangkan pada pengujian validitas dengan uji homogenitas data dan uji korelasional antara skor masing-masing butir dengan skor total (Pearson Correlation) menunjukkan korelasi yang positif dan tingkat signifikan pada level 0,01dan 0,05. Dari hasil tersebut dapat diartikan bahwa pertanyaan-pertanyaan yang mengukur variabel informasi akuntansi, ketidakpastian lingkungan, ketidakpastian tugas, dan kinerja manajerial dapat dipergunakan dan valid. Hasil uji reliabilitas dan validitas disajikan pada tabel 4 dan 5 berikut.

\begin{tabular}{clcc}
\hline No. & \multicolumn{1}{c}{ Variabel } & Nilai Cronbach Alpha & Keterangan \\
\hline 1 & Informasi Akuntansi & 0,739 & Reliabel \\
2 & Ketidakpastian Lingkungan & 0,813 & Reliabel \\
3 & Ketidakpastian Tugas & 0,743 & Reliabel \\
4 & Kinerja Manajerial & 0,764 & Reliabel \\
5 & Strategi Bisnis & 0,882 & Reliabel \\
\hline
\end{tabular}

Sumber: data primer diolah 2009

\begin{tabular}{clccc}
\hline No & \multicolumn{1}{c}{ Variabel } & Kisaran Korelasi & Signifikansi & Keterangan \\
\hline 1 & Informasi Akuntansi & $0,412^{* *}-0,713^{* *}$ & 0,001 & Valid \\
2 & Ketidakpastian Lingkungan & $0,585^{* *}-0,771^{* *}$ & 0,001 & Valid \\
3 & Ketidakpastian Tugas & $0,328^{* *}-0,671^{* *}$ & 0,001 & Valid \\
4 & Strategi Bisnis & $0,944^{* *}-0,947^{* *}$ & 0,001 & Valid \\
5 & Kinerja Manajerial & $0,279^{*}-0,771^{* *}$ & 0,005 & Valid \\
\hline
\end{tabular}

** Signifikan pada $\pm 0,001$

* Signifikan pada $\pm 0,005$

Sumber: data primer diolah 2009

\subsection{Uji Normalitas}

Uji normalitas bertujuan untuk menguji apakah dalam model regresi, variabel pengganggu atau residual memiliki distribusi normal. Salah satu cara untuk mengetahui residual suatu model berdistribusi normal atau tidak dengan menggunakan Histogram dan Normal probability plot dari residual tersebut.

Dari histogram persamaan 2, 3 dan 4 data distribusi residu menunjukkan distribusi normal. Juga pada normal probability plot dapat dilihat sebaran error masih berada pada sekitar garis lurus. Hal ini menunjukkan model regresi persamaan 2, 3 dan 4 memenuhi asumsi normalitas atau residu dari model tersebut berdistribusi normal. 


\subsection{Uji Asumsi Klasik}

Teknik analisis statistik yang digunakan dalam studi ini adalah analisis regresi sederhana dan berganda sebagai model yang memprediksi hubungan kausal antara variabel dependen dengan beberapa variabel independen. Model regresi linear sederhana untuk menguji pengaruh informasi akuntansi terhadap kinerja manajerial. Sedangkan pengaruh ketiga variabel moderating (ketidakpastian lingkungan, ketidakpastian tugas, dan strategi bisnis) terhadap kinerja manajerial dianalisis dengan menggunakan model Moderated regression analysis (MRA). Dengan menggunakan software statistik SPSS ver 17, diperoleh hasil regresi sebagai berikut:

\section{Persamaan 1}

$$
\begin{aligned}
\mathrm{KM}= & 11,396+0,718 \mathrm{INF} \\
& (4,188)(8,542) \\
& \mathrm{R}^{2}=0,511 \\
& \text { F Hitung }=72,962
\end{aligned}
$$

\section{Persamaan 2}

$$
\begin{aligned}
\mathrm{KM}= & 47,138-0,369 \mathrm{INF}-1,535 \mathrm{KL}+0,046 \mathrm{INF}^{*} \mathrm{KL} \\
& (2,941)(-0,695)(-2,163)(1,980) \\
& \mathrm{R}^{2}=0,416 \\
& \mathrm{R}^{2} \text { Adjusted }=0,389 \\
& \text { F hitung }=15,66 \\
& \mathrm{DW} \quad=1,778
\end{aligned}
$$

\section{Persamaan 3}

$$
\begin{aligned}
\mathrm{KM}= & 4,652+0,959 \mathrm{INF}+0,247 \mathrm{KT}-0,09 \mathrm{INF} * \mathrm{KT} \\
& (0,660)(2,886)(0,667)(0,211) \\
& \mathrm{R}^{2}=0,525 \\
& \mathrm{R}^{2} \text { Adjusted }=0,504 \\
& \text { F hitung }=24,357 \\
& \mathrm{DW} \quad=1,471
\end{aligned}
$$

\section{Persamaan 4}

$$
\begin{aligned}
\mathrm{KM}= & -14,144+1,288 \mathrm{INF}+7,666 \mathrm{ST}-0,182 \mathrm{INF} * \mathrm{ST} \\
& (-1,399)(3,901)(3,445)(-2,557) \\
& \mathrm{R}^{2}=0,772 \\
& \mathrm{R}^{2} \text { Adjusted }=0,761 \\
& \text { F hitung }=74,335 \\
& \mathrm{DW} \quad=1,611
\end{aligned}
$$

a. Multikolonieritas

Dalam studi ini, uji yang dilakukan untuk melihat permasalahan di atas adalah dengan berdasarkan pada pendekatan pertama, yaitu didasarkan pada besarnya condition index dari proses Collinearity Index.

Dengan melihat nilai Condition Index pada Collinearity Diagnostic dapat dijelaskan bahwa pada persamaan 2, 3 dan 4 variabel ketidakpastian lingkungan, ketidakpastian tugas dan variabel strategi bisnis mengalami masalah multikolinier. Ini ditunjukkan dengan nilai Condition Index yang lebih besar dari 30 untuk ketiga variabel tersebut.

Persamaan ke 2, mengalami masalah mutikolinieritas, karena variabel moderating ketidakpastian lingkungan mempunyai nilai condition index sebesar 183,616. Persamaan ke 3 juga mengalami masalah mutikolinieritas, karena variabel moderating ketidakpastian tugas mempunyai nilai condition index sebesar 137,287. Dan persamaan ke 4 juga mengalami masalah mutikolinieri- 


\section{Pengaruh Informasi} Akuntansi...

Tabel 6: Ringkasan Persamaan Regresi tas, karena variabel moderating strategi bisnis mempunyai nilai condition index sebesar 183,575.

b. Otokorelasi

Nilai DW tabel pada tingkat signifikansi 5\% , diperoleh nilai $\mathrm{d}_{1}$ sebesar 1,49 dan nilai $d_{u} 1,74$. Untuk persamaan 2 , nilai DW hitung sebesar 1,778. Jika di bandingkan dengan nilai DW tabel pada tingkat signifikansi 5\%, nilai tersebut terletak di atas $\mathrm{d}_{\mathrm{u}}$ sehingga dapat disimpulkan persamaan 2 menghadapi masalah otokorelasi.

Untuk persamaan 3, nilai DW hitung sebesar 1,471. Jika di bandingkan dengan nilai DW table pada tingkat signifikansi 5\%, nilai tersebut terletak lebih kecil dari $\mathrm{d}_{1}$, sehingga dapat disimpulkan persamaan 3 menghadapi masalah otokorelasi.

Sedangkan persamaan 4, nilai DW hitung sebesar 1,611. Jika di bandingkan dengan nilai DW table pada tingkat signifikansi 5\%, nilai tersebut terletak diantara $d_{1}$ dan $d_{u}$ sehingga persamaan 4 tidak dapat disimpulkan, apakah ada atau tidak masalah otokorelasi.

c. Heteroskedastisitas

Untuk melihat ada atau tidaknya heteroskedastisitas pada penelitian ini, dengan bantuan SPSS Ver. 17, dapat dilihat dengan plot khusus dari masingmasing persamaan. Dari output scatter plot persamaan 2, 3 dan 4 terlihat pancaran data di atas tidak menunjukkan atau menggambarkan sebuah pola tertentu, hal ini menunjukkan bahwa model persamaan 2 yang melihat pengaruh variabel moderating ketidakpastian lingkungan terhadap kinerja manajerial tidak mengalami masalah heteroskedastisitas.

\subsection{Uji Hipotesis}

Berdasarkan hasil pengolahan data dengan menggunakan model MRA dapat disajikan ringkasan persamaan regresi sebagai berikut:

\begin{tabular}{|c|c|c|c|c|c|c|c|}
\hline \multirow[t]{2}{*}{ Hipotesis } & \multirow[t]{2}{*}{ R Square } & \multirow{2}{*}{$\begin{array}{l}\text { Adjusted } \\
\text { R Square }\end{array}$} & \multicolumn{2}{|c|}{ Uji Signifikansi } & \multicolumn{2}{|c|}{$\begin{array}{c}\text { Uji Signifikasi } \\
\text { Parameter }\end{array}$} & \multirow[t]{2}{*}{ Keterangan } \\
\hline & & & $\mathbf{F}$ & Sig & $t$ & Sig & \\
\hline \multicolumn{8}{|l|}{$\mathrm{H}_{1}$} \\
\hline INF - KM & 0,518 & 0,511 & 72,962 & 0,000 & 8,542 & 0,000 & Signifikan \\
\hline \multicolumn{8}{|l|}{$\mathrm{H}_{2}$} \\
\hline INF, KL, INF*KL - KM & 0,416 & 0,389 & 15,665 & 0,000 & & & Signifikan \\
\hline INF & & & & & $-0,695$ & 0,490 & Tidak Signifikan \\
\hline KL & & & & & $-2,163$ & 0,034 & Signifikan \\
\hline INF*KL & & & & & 1,980 & 0,052 & Signifikan \\
\hline \multicolumn{8}{|l|}{$\mathrm{H}_{3}$} \\
\hline INF, KT, INF*KT - KM & 0,525 & 0,504 & 15,665 & 0,000 & & & Signifikan \\
\hline INF & & & & & 2,886 & 0,005 & Signifikan \\
\hline KL & & & & & 0,667 & 0,507 & Tidak Signifikan \\
\hline INF*KL & & & & & $-0,748$ & 0,457 & Tidak Signifikan \\
\hline \multicolumn{8}{|l|}{$\mathrm{H}_{4}$} \\
\hline INF, ST, INF*ST - KM & 0,772 & 0,761 & 74,335 & 0,000 & & & Signifikan \\
\hline INF & & & & & 3,901 & 0,000 & Signifikan \\
\hline ST & & & & & 3,445 & 0,001 & Signifikan \\
\hline INF*ST & & & & & $-2,557$ & 0,013 & Signifikan \\
\hline
\end{tabular}

Sumber: data primer diolah 2009

a. Informasi Akuntansi Berpengaruh Terhadap Kinerja Manajerial $\left(\mathrm{H}_{1}\right)$

Pengujian hipotesis 1 dilakukan dengan melihat interaksi antara variabel informasi akuntansi dengan kinerja manajerial (persamaan 1), menunjukkan besarnya adjusted $\mathrm{R}^{2}$ adalah 0,511 , hal ini berarti $51,1 \%$ variasi kinerja manajerial dapat dijelaskan oleh variasi dari variabel informasi akuntansi, sedangkan sisanya 48,9\% dijelaskan oleh sebab-sebab yang lain di luar model. Dari model regresi tampak pengaruh variabel informasi akuntansi signifikan pada á 0,05 , hal ini berarti bahwa variabel kinerja manajerial dipengaruhi oleh informasi akuntansi.

b. Ketidakpastian Lingkungan Memoderasi Pengaruh Informasi Akuntansi Terhadap Kinerja Manajerial $\left(\mathrm{H}_{2}\right)$. 
Hasil pengujian hipotesis 2 dapat dilihat menunjukkan besarnya adjusted $\mathrm{R}^{2}$ adalah 0,389, hal ini berarti 38,9\% variasi Kinerja Manajerial dapat dijelaskan oleh variasi variabel independen Informasi Akuntansi, Ketidakpastian Lingkungan, dan MDINFKL (INF*KL), sedangkan sisanya 61,1\% dijelaskan oleh sebab-sebab lain di luar model. Dari uji statistik F hitung diperoleh sebesar 15,665 pada $\alpha 0,05$, sehingga model regresi dapat digunakan untuk memprediksi Kinerja Manajerial atau dapat dikatakan bahwa Informasi Akuntansi, Ketidakpastian Lingkungan, dan MDINFKL (INF*KL) secara bersama-sama berpengaruh terhadap Kinerja Manajeril. Sedangkan dari uji parameter individual diperoleh hasil variabel Informasi Akuntansi tidak berpengaruh terhadap Kinerja Manajerial pada $\alpha$ 0,05 dan variabel MDINFKL yang merupakan interaksi antara Informasi Akuntansi dan Ketidakpastian Lingkungan secara signifikan berpengaruh terhadap Kinerja Manajerial. Sehingga dapat diartikan bahwa variabel Ketidakpastian Lingkungan merupakan variabel moderating atau memoderasi pengaruh antara Informasi Akuntansi dan Kinerja Manajerial.

c. Ketidakpastian Tugas Memoderasi Pengaruh Informasi Akuntansi Terhadap Kinerja Manajerial $\left(\mathrm{H}_{3}\right)$.

Hasil pengujian hipotesis 3 menunjukkan besarnya adjusted $\mathrm{R}^{2}$ adalah 0,504, hal ini berarti 50,4\% variasi Kinerja Manajerial dapat dijelaskan oleh variasi variabel Informasi Akuntansi, Ketidakpastian Tugas, dan MDINFKT (INF*KT), sedangkan sisanya 49,6\% dijelaskan oleh sebab-sebab lain di luar model. Dari uji statistik F diperoleh sebesar 24,357 pada $\alpha 0,05$, sehingga dapat dikatakan bahwa model regresi dapat digunakan untuk memprediksi Kinerja Manajerial atau dapat dikatakan bahwa Informasi Akuntansi, Ketidakpastian Tugas, dan MDINFKT (INF*KT) secara bersama-sama berpengaruh terhadap Kinerja Manajerial. Sedangkan dari uji parameter individual diperoleh hasil variabel Informasi Akuntansi secara statistik berpengaruh terhadap Kinerja Manajerial pada $\alpha$ 0,05 dan variabel MDINFKT yang merupakan interaksi antara Informasi Akuntansi dan Ketidakpastian Tugas tidak signifikan. Sehingga dapat diartikan bahwa variabel Ketidakpastian Tugas bukan merupakan variabel moderating atau tidak memoderasi pengaruh antara Informasi Akuntansi dan Kinerja Manajerial.

d. Strategi Bisnis Memoderasi Pengaruh Informasi Akuntansi Terhadap Kinerja Manajerial $\left(\mathrm{H}_{4}\right)$.

Hasil pengujian hipotesis 4 menunjukkan besarnya adjusted $\mathrm{R}^{2}$ adalah 0,761, hal ini berarti 76,1\% variasi Kinerja Manajerial dapat dijelaskan oleh variasi variabel independen Informasi Akuntansi, Strategi Bisnis, dan MDINFST (INF*ST), sedangkan sisanya $23,9 \%$ dijelaskan oleh sebab-sebab lain di luar model. Dari uji statistik F diperoleh sebesar 74,335 pada $\alpha 0,05$, sehingga dapat dikatakan bahwa model regresi dapat digunakan untuk memprediksi Kinerja Manajerial atau dapat dikatakan bahwa Informasi Akuntansi, Strategi Bisnis, dan MDINFST (INF*ST) secara bersama-sama berpengaruh terhadap Kinerja Manajerial. Sedangkan dari uji parameter individual diperoleh hasil variabel Informasi Akuntansi berpengaruh secara signifikan terhadap Kinerja Manajerial pada $\alpha$ 0,05 dan variabel MDINFSF yang merupakan interaksi antara Informasi Akuntansi dan Strategi Bisnis juga secara signifikan berpengaruh terhadap Kinerja Manajerial. Sehingga dapat diartikan bahwa variabel Strategi Bisnis merupakan variabel moderating atau memoderasi pengaruh antara Informasi Akuntansi dan Kinerja Manajerial.

\section{Pembahasan}

Berdasarkan hasil pengujian hipotesis 1 dapat dijelaskan, bahwa informasi akuntansi berpengaruh terhadap kinerja manajerial. Hal ini sesuai dengan penelitian Hirst (1981) yang menjelaskan bahwa informasi akuntansi dapat digunakan oleh manajemen untuk proses perencanaan, koordinasi dan penilaian evaluasi 


\section{Pengaruh Informasi Akuntansi...}

yang nantinya dijadikan pedoman di masa mendatang. Penggunaan informasi akuntansi dapat berdampak positif terhadap bawahan dan informasi akuntansi baik sebagai penilaian prestasi seseorang. Begitu juga dengan David (2001) yang menjelaskan bahwa penggunaan informasi akuntansi berpengaruh positif terhadap kinerja manajer. Akuntansi dapat memberikan informasi yang dibutuhkan oleh pelaku bisnis dalam menjalankan fungsi manajemen yang penting dalam menentukan langkah stratregis suatu organisasi untuk mencapai tujuan.

Hasil temuan untuk hipotesis 2, Ketidakpastian lingkungan memoderasi pengaruh informasi akuntansi terhadap kinerja manajerial. Hasil penelitian ini sesuai dengan penelitian Govindarajan (1986) yang menguji hubungan ketidakpastian lingkungan terhadap kinerja perusahaan tanpa secara eksplisit mempertimbangkan peran informasi sistem akuntansi manajemen. Kondisi ketidakpastian lingkungan yang tinggi membuat informasi merupakan komoditi yang sangat berguna sekali dalam proses kegiatan perencanaan dan kontrol dalam suatu organisasi.

Hasil temuan untuk hipotesis 3, Ketidakpastian tugas tidak memoderasi pengaruh informasi akuntansi terhadap kinerja manajerial. Hasil ini tidak sesuai dengan penelitian David (2001) yang menjelaskan bahwa informasi akuntansi dan ketidakpastian tugas memiliki pengaruh yang signifikan terhadap kinerja manajerial. Namun hasil ini mendukung penelitian Fazli (2000), yang menyatakan bahwa ketidakpastian tugas tidak memoderasi pengaruh informasi akuntansi terhadap kinerja manajerial.

Hasil temuan hipotesis 4, yang menyatakan bahwa Strategi bisnis memoderasi pengaruh informasi akuntansi terhadap kinerja manajerial sesuai dengan penelitian Govindarajan dan Gupta (1985)Simon (1997) dalam Yubiharto (2003) menegaskan bahwa informasi akuntansi dibutuhkan dalam penetapan strategi bisnis perusahaan dan menyatakan menyatakan bahwa penekanan informasi akuntansi lebih besar dalam perusahaan yang meadopsi tipe build and prospector strategy.

Dari penjelasan tersebut, dapat dikatakan bahwa informasi akuntansi dapat digunakan oleh manajemen dalam perencanaan, koordinasi, dan penilaian prestasi seseorang dan diperlukan pula penyesuaian terhadap perubahan lingkungan bisnis dengan menyusun strategi bisnis yang lebih baik agar kinerja manajer lebih meningkat sehingga prestasi perusahaan pun meningkat dengan kata lain ketidakpastian lingkungan, dan strategi bisnis memiliki pengaruh langsung terhadap kinerja manajerial secara bersama-sama dengan informasi akuntansi dan ketidakpastian lingkungan serta strategi bisnis memoderasi pengaruh informasi akuntansi terhadap kinerja manajerial.

\section{SIMPULAN}

Penelitian ini memberikan indikasi pentingnya informasi akuntansi dalam melakukan fungsi-fungsi manajemen dan menilai prestasi seseorang. Hasil penelitian ini mempertegas dan mendukung temuan Hirst (1981) yang menjelaskan bahwa informasi akuntansi dapat digunakan oleh manajemen untuk proses perencanaan, koordinasi dan penilaian evaluasi yang nantinya dijadikan pedoman di masa mendatang. Penggunaan informasi akuntansi dapat berdampak positif terhadap bawahan dan informasi akuntansi baik sebagai penilaian prestasi seseorang. Begitu juga dengan David (2001) yang menjelaskan bahwa penggunaan informasi akuntansi berpengaruh positif terhadap kinerja manajer.

Hasil penelitian ini juga mempertegas terdapat pengaruh simultan yang signifikan antara ketidakpastian lingkungan, strategi bisnis, dan informasi akuntansi terhadap kinerja manajer sehingga kedua variabel yang diajukan sebagai variabel moderating memoderasi pengaruh informasi akuntansi terhadap kinerja manajer seperti yang dihipotesiskan. 
Evaluasi atas hasil penelitian ini harus mempertimbangkan beberapa

keterbatasan yang mungkin mempengaruhi hasil penelitian, antara lain:

a. Kehandalan validitas dan reliabilitas instrumen yang digunakan dalam penelitian ini nampak belum teruji dengan baik, karena terdapat beberapa indikator yang dieliminasi (validasi). Peneliti menduga kemungkinan adanya faktor lain yaitu penerjamahan yang kurang baik, terutama setting bahasa yang sesuai dengan kondisi responden di Indonesia.

b. Penggunaan instrumen berupa persepsi akan menimbulkan masalah jika persepsi tersebut berbeda dengan keadaan sebenarnya.

c. Penggunaan self rating pada pengukuran kinerja manajerial dapat menyebabkan adanya kecenderungan para responden mengukur kinerja mereka lebih tinggi daripada yang sebenarnya, sehingga penpenilaian kinerja cenderung menjadi lebih tinggi.

d. Hasil penelitian ini tidak dapat digeneralisasi yang lebih luas karena penelitian dilakukan pada BPR di Kabupaten Bogor.

\section{Rekomendasi}

a. Penelitian mendatang dapat mempertimbangkan sumber daya lainnya yang dimiliki oleh perusahaan yang dapat meningkatkan kinerja manajerial.

b. Penelitian selanjutnya dapat menggunakan ketiga variabel kontijensi yang diajukan tidak sebagai variabel moderating karena beberapa peneliti menyatakan bahwa ketiga variabel tersebut berpengaruh langsung terhadap kinerja manajerial. Selain itu pula dapat digunakan variabel kontijensi yang lain, seperti desentralisasi dan komitmen.

c. Perlu diuraikan jenis-jenis strategi bisnis dalam analisisnya untuk menjelaskan jenis-jenis strategi bisnis yang digunakan dalam perusahaan.

d. Penelitian ini menggunakan metode survey yang dapat menyebabkan tingkat response rate menjadi rendah, sehingga mungkin bisa digunakan metode lain.

\section{DAFTAR PUSTAKA}

Belkoui. 1986. Quality, Strategy, and Competitiveness. California Management Review. Spring, pp. 55-67

David. E. 2001. "Pengaruh Informasi Akuntansi Terhadap Kinerja Manajer Dengan Ketidakpastian Tugas Sebagai Variabel Moderating". Tesis Magister Sains Akuntansi Undip Semarang (Tidak Dipublikasikan)

Gordon, L.A dan Narayana, V.K. 1984. "Management Control System Perceived Environmental Uncertainty And Organization Structure: An Empirical Investigation". Accounting, Organization, And Society, Vol.9, pp.33-47

Govindarajan. 1986."Impact of Participation in the Budgetary Process on Managerial Attitudes and Performance:Universalistic and Contigency Perspectives". Decision Sciences 17:496-516

Handoko. 2001. Bank dan Lembaga Keuangan. BPFE UII., Yogyakarta

Hair, J.R., Anderson, R.E., Tatham,R.L., Black,W.C. 1995. "Multivariate Data Ana' lyst”. Fifth edition. Prentice Hall International.Inc

Hirst, Mark K. 1981, "Accounting Information And The Evaluation Of Subordinate Performance: A Situational Approach". The Accounting Review, Vol. LVI, No. 4, Oktober pp.771-784

Imron (2003) 2004. "Analisis faktor-faktor yang mempengaruhi pemanfaatan Teknologi Informasi dan Pengaruhnya terhadap Kinerja Manajerial pada Perusahaan Manufaktur di Kalimantan Selatan”. Program Studi Magister Akuntansi Universitas Diponegoro (tidak dipublikasikan). 
Pengaruh

Informasi

Akuntansi...

126
Imam Ghozali. 2005. Aplikasi Analisis Multivariate Dengan Program SPSS: Edisi Kedua Badan Penerbit Undip Semarang

Indriantoro, Nur dan Bambang Supomo. 1999. Metode Penelitian Bisnis: Untuk Akuntansi dan Manajemen. BPFE. Yogyakarta

Komara, A. 2003. "Analisis Faktor-Faktor Yang mempengaruhi Kinerja Sistem Informasi”. Tesis Magister Sains Akuntansi Undip Semarang (Tidak dipublikasikan)

Mardiyah dan Gundono. 2002. Pengaruh sistem pengukuran kinerja, sistem reward, dan profit center terhadap hubungan antara total quality manajement dengan kinerja manajerial. Seminar Nasional Akuntansi 8: pp. 565-585

Maryanti. 2005. Analisis penerimaan auditor atas Dysfungtional Audit Behavior pendekatan karakteristik personal auditor (studi empiris pada kantor akuntan publik di Jawa). Tesis S2 Magister Akuntansi Universitas Diponegoro (tidak dipublikasikan).

Nunnaly.J.C.And I.H., Bernsten. 1994. Psycometric Theory, McGraw-Hill. 3 th.Ed

Oktavianus, P. 2002. "Pengaruh Ketidapastian Lingkungan Terhadap Hubungan Antara Karakteristik Sistem Penganggaran Dengan Kinerja Manajerial Pada Perusahaan Industri Makassar". Tesis Magister Sains Akuntansi Undip Semarang (Tidak Dipublikasikan)

Sugiyono. 2005. Metode penelitian bisnis,Alfabeta, Bandung

Syam, F. 2000. "Informasi Akuntansi, Ketidakpastian Tugas Dan Perilaku Manajer: Suatu Eksperimen Semu”. Tesis Program Pasca Sarjana Studi Akuntansi UGM (Tidak Dipublikasikan)

Yubiharto. 2003. "Pengaruh Ketidakpastian Lingkungan Dan Strategi Bisnis Terhadap Kinerja Manajerial Dengan Karakteristik Sistem Akuntansi Manajemen Sebagai Variabel Intervening”. Tesis Magister Sains Akuntansi Undip Semarang (Tidak Dipublikasikan) 